\title{
KOMUNIKACIJA
}

\section{POLITINIAI RYŠIAI SU VISUOMENE: SIEKIS PATEIKTI VISUOMENEI REALIAI ATLIEKAMUS DARBUS AR PRIEMONE் OPONENTUS KALTINTI NETINKAMA VEIKLA}

Doc. DR. Renata MatKevičIEnĖ

Vilniaus universiteto Komunikacijos fakultetas

Vilnius University Faculty of Communication

Sauletekio al. 9, LT-10222 Vilnius

El.paštas renata.matkeviciene@kf.vu.lt

\section{Santrauka}

Viešojoje erdveje, ypač artèjant politiniams rinkimams, aštrèja politiku tarpusavio komunikacines kovos, kuriose jie dažnai vieni kitus kaltina viešuju ryšiu technologiju naudojimu. Politika yra ta sritis, kuri ir paskatino šiuolaikiniu ryšiu su visuomene atsiradima, kai yra informuojama visuomene, pristatomos idejos, organizuojamos diskusijos ir pan. Politikoje ryšiai su visuomene yra bütini ne tik politiniu rinkimu kampaniju metu, bet ir kasdien, nes tik politikai ir politines institucijos gali užtikrinti ir pačios politikos vykdymą: formuoti vyriausybes, koalicijas, spręsti valstybes svarbos klausimus, ieškoti kompromisu derantis partijoje ar su skirtingu partiju atstovais, verslininkais, kitu šaliu politikais. Politiniai ryšiai su visuomene apreipia labai platu komunikacijos spektrą, tad tampa apmaudu, kai viešojoje erdvéje politikai viešuosius ryšius vertina tik kaip būda büti matomiems, populiariems. 
Šio straipsnio tikslas - atskleisti politiniu ryšiu su visuomene ypatumus, išryškinti politiniu ryšiu su visuomene dalyvius, veiklos principus, siekiant paneigti žiniasklaidoje ir visuomeneje vyraujančius mitus apie viešuju ryšių veikla.

Straipsnyje analizuojama politiniu ryšiu su visuomene veikla, aptariama jos specifika ir aspektai. Autorè siekia ne tik išryškinti veiklos specifika, bet ir aptarti viešojoje erdvejje egzistuojančius mitus, siejamus su politine komunikacija, viešaisiais ryšiais.

Reikšminiai žodžiai: politiniai ryšiai su visuomene; žiniasklaida; politikai; politinès institucijos; valdžios institucijos; viešieji ryšiai; ivaizdis.

\section{Ivadas}

Politikų pasisakymuose, žiniasklaidos pateikiamose politinių sprendimų ar politikų veiksmų interpretacijose Lietuvoje girdèti priekaištų dèl vykdomos viešųų ryšių veiklos, kuria yra paaiškinami ar paslepiami atitinkami politikų oponentų veiksmai. Žinoma, dẻl viešųų ryšių veiklos specifikos: veiklos sąsajos su reklama, žiniasklaida, matomumo kūrimu, ivvaizdžio formavimu ir pan., ji mistifikuojama, jai suteikiamos galios ar svarba, kurios realiai viešieji ryšiai neturi, tačiau tiek politinèje kovoje su konkurentais, tiek siekiant patraukliai, j̇domiai ir intriguojančiai pristatyti politikų veiksmus viešieji ryšiai tampa tinkama tema.

Bene dažniausiai politikai, komentuodami kolegų (politikų, atstovaujančių kitoms politinèms partijoms) veiksmus, ịtraukia ir viešųjų ryšių aspektą. Štai straipsnyje „Rinkèjų viliotojai susipainiojo savo viešųjų ryšių voratinklyje “1, parašytame opozicijos atstovo, galima

1 Rudžionis, G. Rinkèjų viliotojai susipainiojo savo viešųjų ryšių voratinklyje [interaktyvus]. Delfi.lt, 2012 m. spalio 4 d. Prieiga per internetą: < http://www.delfi. 1t/archive/grudzionis-rinkeju-viliotojai-susipainiojo-savo-viesuju-rysiu-voratinkly je.d?id=59681197\#ixzz2s3vgxSYk>. 
rasti gana vaizdingą viešųų ryšių taikymo savivaldos veikloje aprašymą: „<...> Viešieji ryšiai dirbo išsijuosę, tik e-bilieto sistema „naudinga" važiuojantiems įstrigo ir sustojo. <..> Prieš žiemą paskelbta oranžinių slidžių akcija būtų laiku, naudinga vilniečiams ir sẻkminga merui viešųjų ryšių prasme. Viešosios nuomonès požiūriu „Šliuožk oranžinėmis slidėmis“ taptų kompensacija ankstesnei žmones mulkinančiai savireklamai ir padètų išsinarplioti iš savo nevykusių viešųjų ryšių voratinklio." Analizuojant politikų pasisakymus viešojoje erdvejje matyti ir kita tendencija: norint parodyti realius veiksmus yra pabrèžiama jų priešprieša viešiesiems ryšiams, kaip antai straipsnyje „Vyriausybės kadrų politikai apskrityse nepadès nè viešieji ryšiai“2 ${ }^{2}$ yra teigiama, kad „Andriaus Kubiliaus Vyriausybè klaidų padarè. Anot jo, Vyriausybès kadrų politikai apskrityse nepadès nè viešieji ryšiai“. Panašų tvirtinimą galima rasti ir kitame straipsnyje „Didžiuojuosi, kad galiu dirbti šioje Vyriausybejje“3, kuriame teigiama, kad „viešieji ryšiai, pripažinsiu, iš tikrųų nèra Andriaus Kubiliaus prioritetas. Kai kas sakys - blogai, tačiau sąžiningas, nuoširdus, negailint nei savęs, nei savo sveikatos darbas, mano giliu ịsitikinimu, ir yra tie tikrieji viešieji ryšiai. Galbūt ne visi šiandien tai supranta, bet turime ugdyti tokią visuomenę ir tokią politinę kultūrą, kad ne politinè pudra per užsakymus žiniasklaidai, ne meilus viešas kalbejjimas siekiant pridengti oligarchinę politikos prigimtị, o atsakomybẻ už krašto ateitị ir sąžiningas kalbejjimas su žmonėmis ir apie bẻdas, ir apie pasiekimus būtų šių dienų XXI amžiaus politikos prioritetas.“

2 Landsbergis, V. Vyriausybès kadrų politikai apskrityse nepadės nè viešieji ryšiai [interaktyvus]. Delfi.lt [parengta pagal Arvydas Jockus, „Valstiečių laikraštis“, 2009 m. vasario 14 d.]. Prieiga per internetą: <http://www.delfi.lt/news/daily/ lithuania/vlandsbergis-vyriausybes-kadru-politikai-apskrityse-nepades-ne-viesiejirysiai.d?id=20572266\#ixzz2s3jXIFLc $>$.

3 Juknevičienè, R. Didžiuojuosi, kad galiu dirbti šioje Vyriausybèje [interaktyvus]. Delfi.lt, $2011 \mathrm{~m}$. gegužès 6 d. Prieiga per internetą: <http://www.delfi. lt/news/ringas/politics/rjukneviciene-didziuojuosi-kad-galiu-dirbti-siojevyriausybeje.d?id=45137245>. 
Taigi iš politikų pasisakymų matyti ir viešųjų ryšių veiklos įtakos ryškinimas, ir jų menkinimas. Dar vienas aspektas, kuris kelia nerimą analizuojant politikų ir žiniasklaidos požiūrị i viešuosius ryšius neteisingas viešųjų ryšių supratimas, tiksliau - tendencingas veiklos traktavimas kaip blogio, kuriuo yra paslepiamos politikų klaidos. Patys politikai, dažnai sekdami žiniasklaidos formuojamu minkštujų naujienų stiliumi, perima populiarųji diskursą ir viešuosius ryšius suvokia kaip blogybę, nors paties kaltintojo veiksmai gali būti vadinami viešaisiais ryšiais (ryšiais su žiniasklaida, sąsajumas su populiariais asmenimis, pan.).

Kadangi viešojoje erdvèje dominuoja ne politikų parengti ir komunikuojami tekstai, o žiniasklaidos atstovų pranešimai, kalbant apie politikų ryšius su visuomene verta analizuoti politikų, politinių institucijų ryšius su žiniasklaida, gal tiksliau - santykius, nes jie lemia ir politiko ar politinès institucijos matomumą, iš dalies vertinimą.

Žurnalistų straipsniuose taip pat matyti kryptingas neigiamas viešųjų ryšių vertinimas, kuris atsiskleidžia iš tendencingai parenkamų pašnekovų ar skambiai pavadintų straipsnių, kuriuose kartais net nekalbama apie viešuosius ryšius. Būna sunku nustatyti, kas yra viešųjų ryšių termino, kaip neigiamos veiklos, ịtraukimo ị viešąji ir ypač politinị diskursą pradininkas, tačiau akivaizdu, kad vienodai sẻkmingai šį triuką taiko tiek politikai, kovojantys su savo oponentais, tiek žurnalistai: „Interpeliacija V. P. Andriukaičiui - viešųjų ryšių akcija?“4, „A. Butkevičius: lenkų pareiškimas trauktis iš koa-

4 Radžiūnas, V. Interpeliacija V. P. Andriukaičiui - viešujų ryšių akcija? [interaktyvus]. Delfi.lt, $2013 \mathrm{~m}$. birželio 14 d. [parengta pagal www.lrt.lt]. Prieiga per internetą: $<$ http://www.delfi.lt/news/daily/lithuania/interpeliacija-v-p-andriukaiciui-viesujurysiu-akcija.d?id=61627821\#ixzz2s3yRKvxI $>$. 
licijos - viešųjų ryšių akcija“5, „Dèl vèliavos reikia diskusijų, ne viešųjų ryšių kampanijų “6 , „Pagiriamasis žodis dešiniesiems ir jų „piarui“" „Viešieji ryšiai padès pamiršti A. Zuoko fiasco“" . Tai tik keletas atvejų, kuriuos galima lengvai rasti viename iš populiariausių naujienų leidinių.

Žiniasklaida, būdama svarbiausia politikų, taip pat ir visuomenès tvarkaraščio formuotoja, didžia dalimi lemia viešųjų ryšių ir jų taikymo politikoje pateikimą ir diskusiją viešajame diskurse.

Ne tik politikai kaltina vieni kitus naudojant viešųjų ryšių technikas, bet ir žurnalistai, norėdami atkreipti žiniasklaidos vartotojų dėmesi $\mathfrak{i}$ atitinkamus politikų poelgius ir siekdami parodyti „nemeilę " politikui ar nepritarimą jo veiksmams, juos aiškina neigiamai - kaip „piarą“ (kitaip - viešuosius ryšius). Būtų galima pateikti I. Makaraitytès $2012 \mathrm{~m}$. straipsnį ${ }^{9}$, kuriame rašoma apie naują viešojo transporto sistemą Vilniuje ir sostinès mero A. Zuoko netinkamus sprendimus, dèl kurių jis yra keiksnojamas, ir dẻl mero viešųjų ryšių, kurie neva padès merui sumažinti kylantị nepasitenkinimą. Straipsnio autorè teigia: „Štai kodèl geras „pijarščikas“ prieš rinkimus toks brangus ir toks reikalingas. Kad mes suprastume pagaliau,

5 A. Butkevičius: lenkų pareiškimas trauktis iš koalicijos - viešųjų ryšių akcija [interaktyvus]. Delfi.lt, $2013 \mathrm{~m}$. vasario $12 \mathrm{~d}$. [parengta pagal www.lrt.lt]. Prieiga per internetą: <http://www.delfi.lt/news/daily/lithuania/abutkeviciuslenku-pareiskimas-trauktis-is-koalicijos-viesuju-rysiu-akcija.d?id=60651447 \#ixzz2s3zZ8NiY>.

6 Valiušaitis, V. Dèl vèliavos reikia diskusijų, ne viešųjų ryšių kampanijų [interaktyvus]. Delfi.lt, $2012 \mathrm{~m}$. rugpjūčio 27 d. Prieiga per internetą: $<$ http://www. delfi.lt/news/ringas/lit/vvaliusaitis-del-veliavos-reikia-diskusiju-ne-viesuju-rysiu-ka mpaniju.d?id=59385593\#ixzz2s41Smgkv $>$.

7 Norkienė, D. Pagiriamasis žodis dešiniesiems ir jų ,piarui““ [ineraktyvus]. Delfi.lt, 2014 m. sausio 23 d. Prieiga per internetą: < http://www.delfi.lt/news/ringas/politics/ d-norkiene-pagiriamasis-zodis-desiniesiems-ir-ju-piarui.d?id=63824776\#ixzz2s4H G0W7n>.

8 Makaraitytè, I. Viešieji ryšiai padès pamiršti A. Zuoko fiasco [interaktyvus]. Delfi.lt, 2012 m. rugsejjo 14 d. Prieiga per internetą: <http://www.delfi.lt/news/ringas/lit/ imakaraityte-viesieji-rysiai-pades-pamirsti-azuoko-fiasko.d?id=59515851>.

9 Ten pat. 
jog problemų išvis nèra. Yra tik nuolat dejuojantys ir valdžiai nedèkingi piliečiai."

Tačiau ar tikrai visi politikų veiksmai yra dèl viešųų ryšių, t. y. tik dèl noro parodyti politiką ar jo veiksmus, priimamus ar siūlomus sprendimus kitaip, nei yra realybeje? Turbūt tai yra viena iš apgaulių: kai neturi argumentų, kurie leistų analizuoti priimamus sprendimus, ieškoti priežasčių, analizuoti įvairių grupių interesus, aiškinti galimas atitinkamų sprendimų pasekmes, paprasčiau apkaltinti vykdant viešuosius ryšius, kurie interpretuojami kaip kalbejimas apie tai, kas yra nedaroma arba kuo norima pridengti netinkamus sprendimus, nevykdomas veiklas ir pan.

Taigi tokie viešojoje erdvejje paplitę viešųjų ryšių politikoje supratimo mitai, eskaluojami tų, kurie tarsi žino ar turètų žinoti, kas yra viešieji ryšiai (politikai, kurie naudojasi viešųjų ryšių specialistų, konsultantų paslaugomis, ir žurnalistai, studijuodami ir dirbdami žurnalisto darbą, dažnai net ir jị keisdami ị viešųjų ryšių specialistų darbą), reikalauja detalesnio požiūrio ị viešuosius ryšius politikoje. Šio straipsnio tikslas - atskleisti politinių ryšių su visuomene ypatumus, išryškinti politinių ryšių su visuomene dalyvius, veiklos principus, siekiant paneigti žiniasklaidoje ir visuomenejje vyraujančius mitus apie viešųjų ryšių veiklą.

\section{Politinių ryšių su visuomene samprata ir taikymas}

Politinių ryšių su visuomene tyrẻjai dažnai cituoja politinę komunikaciją tiriančio mokslininko Briano $\mathrm{McNairo}^{10}$ teiginius, kad ryšiai su visuomene yra kaip išradimai, kurie jau padaryti ir kurių svarba ir reikšmè taip pat yra akivaizdūs. Kaip teigia McNairas, „elektra ar atomine bomba, kurios jau išrastos ir tų išradimų paneigti negalime, kaip

${ }^{10}$ McNair, B. PR must die: spin, anti-spin and political public relations in the UK, 1997-2004. Journalism studies. 2004, vol. 5, no. 3, p. 325-338. Prieiga per internetą: $<$ http://dx.doi.org/10.1080/1461670042000246089>. 
ir to, kad ryšiai su visuomene yra neatskiriama šiuolaikinio politinio proceso dalis" ${ }^{\text {"11 }}$. Politiniai ryšiai su visuomene, kaip komunikacinė veikla, yra igyvendinami jau beveik šimtmetị (turint omenyje veiklą, kuri yra vadinama politiniais ryšiais su visuomene ir kuri sietina tiek su politinių partijų, tiek su vyriausybès viešąja komunikacija), todèl kiekvieną kartą kalbėti apie politinių ryšių su visuomene kilmę ir taikymą politikoje, atrandant politinių ryšių su visuomene sąsajas su šalies ir vyriausybès vykdoma informacijos politika, kultūrine diplomatija, propaganda ir pan., yra tarsi grịžimas ị praeitị, neįžvelgiant politinių ryšių su visuomene esmès - padèti politikams, politinėms institucijoms (politinėms partijoms, judejjimams, valdžios institucijoms) užmegzti santykius su suinteresuotųjų grupèmis, pristatyti ir diskutuoti aktualiomis temomis, ieškant geriausio sprendimo būdo. Politinių ryšių su visuomene tikslai dažnai susiję su komunikacinėmis veiklomis, kuriomis siekiama atkreipti dėmesị $\mathfrak{i}$ tam tikras politines problemas arba tą dėmesị sumažinti. Kaip teigia Romy Fröhlich ir Burkhardas Rüdigeris $^{12}$, esminis politinių ryšių su visuomene tikslas yra tinkamai naudoti žiniasklaidą komunikuojant politines žinutes, sprendimus ir vertinimą, tokia komunikacija siekiant gauti palaikymą vykdomai politikai ar politinėms kampanijoms.

Žinoma, gali atrodyti, kad politiniai ryšiai su visuomene yra propagandos, melo įrankiai, kuriais viešojoje erdveje naudojasi politinès sferos veikejjai, bet iš tiesų, kaip teigia ir McNairas, tai menkai susiję su tikrąja politinių ryšių su visuomene esme - suteikti politikos veikejjams komunikacines „galimybes (priemones ir technikas), nesvarbu, ar jie yra dešinieji ar kairieji, valdančiojoje partijoje ar opozicijoje“"13.

${ }^{11}$ Ten pat, p. 327.

12 Froehlich, R., Rüdiger, B. Framing political public relations: measuring success of political communication strategies in Germany. Public relations review. 2006, vol. 32, p. 18(18-25). Prieiga per internetą: <sciencedirect.com>.

${ }_{13}$ McNair, B. PR must die: spin, anti-spin and political public relations in the UK, 1997-2004. Journalism studies. 2004, vol. 5, no. 3, p. 337. Prieiga per internetą: $<$ http://dx.doi.org/10.1080/1461670042000246089>. 
Mokslininkai pabrėžia „politinių ryšių su visuomene pagalbą stiprinant demokratiją “14 ${ }^{14}$ nes būtent dèl politinių ryšių su visuomene veiklos kuriamas politinis žinojimas, yra pristatomos politinès idejjos, jos susiejamos su atitinkamais politikais ar politinėmis institucijomis, jų siūlomais sprendimais, o tai lemia suinteresuotųjų įtraukimą i politinès komunikacijos procesus, kitaip sakant, politiniais ryšiais su visuomene i viešąją erdvę yra „iškeliami“ politikai, politinès institucijos, jų veikla, viešos diskusijos, ị kurias ịtraukiami ir kiti suinteresuotieji, sudarant sąlygas visiems politinès sferos veikejjams (politikams, politinėms institucijoms, žiniasklaidai, piliečiams, ịvairioms organizacijoms) įsitraukti i politinę komunikaciją.

Politinių ryšių su visuomene dalyviais reikètų ìvardyti ne tik politikus, politines institucijas ir kitus suinteresuotuosius, kuriems yra skiriami komunikaciniai pranešimai, tačiau ir kitus politinès komunikacijos dalyvius, tokius kaip valdžios institucijų viešųjų ryšių ir atstovo spaudai tarnybos, rengiančios pranešimus apie atitinkamas veiklas, kurios aktualios suinteresuotiesiems, politinių partijų viešųjų ryšių tarnybos, asmenys, atsakingi už partijų komunikaciją (šių institucijų veikla ypač išryškẻja per politines rinkimų kampanijas, visuomenejje svarstant atitinkamas problemas, kai yra organizuojami mitingai, akcijos, kt.). Taip pat politinių ryšių su visuomene dalyviams reikètų priskirti ir kitų institucijų, nesusijusių su politika, ịsitraukimą ì politinę komunikaciją, paprastai tai vyksta svarstant aktualius visuomenei klausimus, problemas, susijusias su institucijos veiklos sritimis (politiniams ryšiams su visuomene yra priskiriama lobistinè veikla), ir, žinoma, viena iš svarbiausių politinių ryšių su visuomene veikẻjų - visuomenè, t. y. ¿̇vairios visuomenès grupès, rinkèjai ${ }^{15}$.

14 Brissenden, J., Moloney, K. Political PR in the 2005 UK general election: winning and losing, with a little help from spin. Journal of marketing management. 2005, vol. 21, no. 9/10, p. 1005-1020. Prieiga per internetą: < http://dx.doi.org/10.1362/ $026725705775194175>$.

15 Тургаев, А.С., Хренов, А.Е. Политология в схемах и комментариях. 2005. 
Politinių ryšių su visuomene tyrëjai Turgajevas ir Chrenovas ryškina politinių ryšių su visuomene funkcinę paskirti, t. y. jie suvokiami kaip tam tikra veikla, kuria yra siekiama aiškių, suplanuotų tikslų. Todèl kalbant apie politinius ryšius su visuomene, pirmiausia akcentuojamas komunikacinių veiksmų planavimas ir siekis sukurti tarpusavio supratimą tarp politiko, politinès institucijos, pilietinio judejjimo ar visuomenès, tačiau atsižvelgiant $\mathfrak{i}$ šiandienos specifiką vis dèlto reikètų labiau ryškinti politikų santykị su suinteresuotaisiais, nes dažnai rinkejjai patenka ị kelias suinteresuotųjų grupes, tad kreipti dèmesi $\mathfrak{i}$ visuomenę ir suprasti ją tik kaip elektoratą būtų didelè politinių ryšių su visuomene klaida. Taip pat ryšiai su visuomene susiję su nuolatine visuomenès nuomonès, nuostatų stebėsena, nors pastaraisiais metais ryškẻja dar vienas svarbus šios veiklos aspektas - stebėti suinteresuotųjų nuotaikas, veiksmus, jų pokyčius, kuriuos sukelia politikų, politinių institucijų vykdoma veikla ir komunikacija apie ją (taip pat ir atsakingų asmenų pasisakymai), kad juos galima būtų taikyti vykdant politinių ryšių su visuomene veiklas. Ir, žinoma, kad politiniai ryšiai su visuomene, kaip komunikacinė veikla, būtų efektyvūs, turi būti įtraukiamos, išbandomos naujos komunikacijos su suinteresuotaisiais priemonès, tai leistų nesikartoti, išsiskirti iš kitų politikų, politinių institucijų vykdomos komunikacijos.

\section{Politiko(s) patrauklumo formavimas naudojant politinių ryšių su visuomene priemones}

Kad visuomenei (rinkèjams) būtų suprantama, politiniais ryšiais su visuomene politika (politiniai sprendimai, politikų ar politinių institucijų idejos, veiksmai ar tam tikros reakcijos ị kylančias problemas) yra „supakuojama“ (tokị terminą pasiūlè Johnas Streetas ${ }^{16}$, t. y. pateikiama populiariai, suprantamai, patraukliai. Galbūt dèl šio siekio politikai

${ }^{16}$ Street, J. Mass media, politics and democracy. Palgrave, 2001, p. 185. 
(politinès partijos, institucijos) ir kaltina vieni kitus dèl viešujų ryšių taikymo, o ne politinių sprendimų prièmimo. Akivaizdu ir tai, kad dèl kintančios visuomenès, rinkèjo, kuris yra pripratęs prie „supakuotos“ politikos, patys politikai ir politinès institucijos yra aktyvūs kalbėtojai, pristatantys save, politines idejas, sprendimus (Johnas Brissendenas ir Kevinas Moloney ${ }^{17}$ siūlo terminą „prisistatymo aktyvumas“ (angl. presentational activism), kuris ir parodo visuomenès skatinamą politinių partijų spaudimą aktyviau pristatyti save, politines idejjas, veiksmus, problemas ir jų sprendimus). Be abejo, „politikos veikejjų siekis valdyti savo prisistatymą“, kaip teigia J. Brissendenas ir K. Moloney ${ }^{18}$, yra nulemti ir žiniasklaidos ịtakos politikos laukui.

Būtent dèl politinių ryšių su visuomene, kaip pastebi McNairas ${ }^{19}$, politikai, ypač užimantys aukštas vadovaujamas pozicijas valstybejje, dèl ryšių su visuomene specialistų veiklos „supakuojant politikus“ ir pateikiant daugiau informacijos apie jų veiklą, perduodant jų komentarus žiniasklaidos auditorijai, tampa labiau matomi ir pasiekiami visuomenei.

Todèl „ryšiai su visuomene politikoje aprèpia ne tik [komunikacijos tam tikromis temomis] strategijas [turima omenyje atitinkamos temos, problemos iškèlimas ị viešąją erdvę ir diskusijų skatinimas; arba atitinkamos temos susiejimas su tam tikru politiku, politine institucija, jos vertybėmis, elgsena ir pan.], bet ir įtikinimo strategijas“20. Politiniai ryšiai su visuomene dažnai siejami su esminemis „ryšių su visuomene technikomis: ryšiais su žiniasklaida, pasakojimų kūrimu, fotografijo-

${ }^{17}$ Brissenden, J., Moloney, K. Political PR in the 2005 UK general election: winning and losing, with a little help from spin. Journal of marketing management. 2005, vol. 21, no. 9/10, p. 1005-1020. Prieiga per internetą: < http://dx.doi.org/10.1362/ $026725705775194175>$.

${ }^{18}$ Ten pat, p. 1006.

${ }^{19}$ McNair, B. An introduction to political communication. $3^{\text {rd }}$ ed. London: Routledge, 2003. $250 \mathrm{p}$.

${ }^{20}$ Froehlich, R., Rüdiger, B. Framing political public relations: measuring success of political communication strategies in Germany. Public relations review. 2006, vol. 32, p. 18(18-25). Prieiga per internetą: <sciencedirect.com> 
mis, ịvykių vadyba ir šūkių kūrimu, kad būtų atkreipiamas rinkèjų dèmesys komunikacijos kampanijų metu“21.

Žinoma, galima rasti pagrindimą, kodèl yra taikomi ryšiai su visuomene siekiant patraukliai pateikti politikų siūlomas idejjas, spręstinas problemas. Kaip teigia Brissendenas ir Moloney ${ }^{22}$, taikant tokias priemones lengviau „patraukti apatišką rinkèją, nes jei politinès partijos ar politikai to nedarytų, jie rizikuotų nepasiekti daugelio savo potencialių rinkejų".

Verta pabrèžti ir tai, kad politiniai ryšiai su visuomene, jų veiklos viešajame diskurse tampa labiau matomos per politinių rinkimų kampanijas, nes tuomet yra siekiama patraukti rinkejjų dèmesi pristatant politikus, politinių institucijų veiklą, keliamas problemas ir siūlomus sprendimus, kt. Tačiau kasdienė politinių ryšių su visuomene veikla yra nukreipta didžia dalimi ne ị elektoratą, o ị kitus suinteresuotuosius: politinius oponentus, verslo institucijas, bendruomenes, visuomenines organizacijas, kitų šalių politikus ir politines institucijas, kita. Kadangi šioms suinteresuotụjų grupėms pasiekti nebūtinas žiniasklaidos tarpininkavimas, rinkejjai nemato tarpusavio ryšių, komunikacijos, santykių tarp šių veikejjų, todèl ir politinius ryšius su visuomene tapatina daugiau su rinkimų komunikacija ir politikų bei politinių institucijų siekiu išryškinti, kurti ir stiprinti įvaizdị, kritikuoti oponentus, kalbėti visuomenei aktualiomis temomis ryškinant dalykus, kurie skaudūs ir svarbūs tam tikroms rinkèjų grupèms; nors iš tiesų ši veikla politiniuose ryšiuose su visuomene svarbi, ji nèra esminè.

Taigi apibendrinant būtų galima išskirti tokias esmines politinių ryšių su visuomene veiklos kryptis:

- politikų, politinių institucijų pri(si)statymas, santykių su

${ }^{21}$ Brissenden, J., Moloney, K. Political PR in the 2005 UK general election: winning and losing, with a little help from spin. Journal of marketing management. 2005, vol. 21, no. 9/10, p. 1005-1020. Prieiga per internetą: < http://dx.doi.org/10.1362/ 026725705775194175>.

${ }^{22}$ Ten pat, p. 1008. 
suinteresuotaisiais sukūrimas ir stiprinimas, jų ittvirtinimas tiek politiniame, tiek viešajame diskursuose (politiniai ryšiai su visuomene suteikia ne vien komunikacijos priemones, bet ir komunikavimo su suinteresuotaisiais strategijas, kurios taikomos siekiant pristatyti politikus, politines partijas ar valdžios institucijas, jų veiklas (sprendžiamas ar iškeliamas viešam svarstymui problemas, priimamus sprendimus, planus, kita);

- komunikacijos strategijos ir taktikos sukūrimas ir atitinkamų komunikacijos priemonių parinkimas bei taikymas politikų, politinių institucijų tarpusavio santykiuose, išryškinant atitinkamų politikų, politinių institucijų stiprybes, o priešininkų - silpnybes (dažnai šios politinių ryšių su visuomene veiklos ir yra matomos oponuojant, konkuruojant su atitinkamu politiku ar politine partija; itin ryškus šios veiklos taikymas yra politinių rinkimų kampanijose siekiant pristatyti atitinkamą politiką ar politinę partiją, susieti ją su tam tikromis temomis, išryškinti siūlomų sprendimų svarbą elektoratui, parodyti oponentų negebejimą spręsti problemas ir pan.);

- $\quad$ komunikacijos veiklos taikomos siekiant sukurti ar užglaistyti konfliktus tarp atskirų politikų, politinių institucijų, kurie kuria politikų ir politinių institucijų ívaizdị ir kurie yra komunikuojami viešajame diskurse (politiniai ryšiai su visuomene gali būti taikomi kaip preventyvi konfliktų sprendimo priemonè, tačiau kartais būtent remiantis šia veikla yra sukeliami, kartais ir sukuriami konfliktai, kuriais siekiama nukreipti auditorijos (suinteresuotųjų, visuomenès) dėmesị nuo diskutuojamų problemų, pateikiamų projektų ar priimamų sprendimų).

Pristatant politinius ryšius su visuomene galima pasiremti ir keliais rusų mokslininkais (Turgajevas, Chrenovas ${ }^{23}$ ), tiriančiais juos, atsižvelgiant $\mathfrak{i}$ šalies ir joje vykdomos komunikacinès veiklos politineje srityje specifiką:

${ }^{23}$ Тургаев, А.С., Хренов, А.Е. Политология в схемах и комментариях. 2005. 
- politinių lyderių ir politinès institucijų (politinių partijų ir valdžios) ideologijos patrauklumo sukūrimas, siekiant sureguliuoti santykius tarp valdžios ir kitų institucijų (svarstant šią veiklą yra ryškinamas politinio lyderio mito kūrimas, galios diskurso įtvirtinimas);

- politikų ir politinių institucijų tarpusavio konkurencinès kovos strategijos ir technologijos, siekiant sėkmès išryškinant lyderius, sukuriant įvairias situacijas, leidžiančias paskatinti lyderių, idèjų „prastūmimą“ politinejje rinkoje (šių technologijų taikymas yra susijęs su politinio lyderio ịvaizdžio formavimu, pristatant ji ịvairiose situacijose, leidžiančiose išryškinti atitinkamas politinio lyderio profesines ir asmenines savybes, elgseną, prisiimamą atsakomybę, kita);

- politinių institucijų, ypač valdžios, tarpusavio santykių (su) formavimas, politinių institucijų autoriteto įtvirtinimas visuomeneje, visuomenès požiūrių stebėsena ir visuomenès informavimas apie atitinkamų politinių institucijų veiklą; kt.

Apžvelgiant pateiktus svarstymus matyti aiškus prieštaravimas, kaip suvokiama politinių ryšių su visuomene veikla: rusų mokslininkai akcentuoja juos kaip politinès valdžios santyki su kitais, siekiant kurti politinès valdžios institucijų ìvaizdžius ir juos įtvirtinti, kovoti su oponentais paveikiant mases ir pan., o Lietuvoje, remiantis vyraujančia Vakarų tradicija, politiniai ryšiai su visuomene suprantami plačiau, neakcentuojant valdžios institucijų ir jų santykio su visuomene kūrimo remiantis įvaizdžių formavimu, siekiu paveikti mases ar susidoroti su priešininkais, o priešingai - taikant komunikacijos priemones ịtikinti oponentus, atitinkamas suinteresuotųu grupes, siūlant ịvairius sprendimus ịtraukti ị sprendimų svarstymą ir prièmimą suinteresuotąsias grupes, t. y. taikant politinius ryšius su visuomene yra siekiama tarpusavio supratimo, bendro susitarimo, paremto atitinkamais pagarba grịstais santykiais komunikuojant politinèmis temomis. 


\section{Politinių ryšių su visuomene vadyba, taikomos priemonès}

Kaip teigia McNairas ${ }^{24}$, politikai XXI amžiuje yra ịtraukiami ị chaotišką informacinę aplinką, todèl politinių ryšių su visuomene užduotis - sukurti tvarką šioje aplinkoje. Dẻl šios priežasties politiniai ryšiai su visuomene gali būti lyginami su informacijos vadybos veikla, siekiant sukurti maksimaliai palankų politiko ar politinès institucijos pristatymą ir išvengti neigiamo. Dèl šios priežasties politiniai ryšiai su visuomene turètų būti analizuojami skiriant juos $\mathfrak{i}$ dvi grupes pagal veiksmų pobūdị: politinių ryšių su visuomene veikla, kuri yra planuojama, nuosekli, kuria siekiama sukurti atitinkamą politiko ar politinès institucijos pristatymą, ịvaizdị ar jị sustiprinti, tačiau ryšiai su visuomene politikoje taip pat yra siejami su netikètais, neplanuotais ịvykiais, kai būtent per politinius ryšius su visuomene, taikant atitinkamas komunikacijos priemones, siekiama sumažinti galimas neigiamas pasekmes politikui, politinei institucijai ar jų ịvaizdžiui.

Remiantis $\mathrm{McNairu}^{25}$, politiniams ryšiams su visuomene būtų galima priskirti tokias komunikacijos veiklas:

- ryšių su žiniasklaida vadybą (teigiamą politikų (ir politinių institucijų) ir žiniasklaidos santykių kūrimą, suvokiant kiekvienos iš šių pusių interesus ir poreikius bei siekiant juos patenkinti taip, kad būtų nauda abiem pusėms, t. y. tiek politikams ir politinėms institucijoms, tiek žiniasklaidai; ryšiai su žiniasklaida yra reikalingi politikams ir politinèms institucijoms pri(si)statyti, pateikti idejas, paaiškinti atitinkamą poziciją, o žiniasklaidai reikia temų, kalbètojų, tad būtent ryšiai su žiniasklaida politiniuose ryšiuose su visuomene yra ta veikla,

${ }^{24}$ McNair, B. PR must die: spin, anti-spin and political public relations in the UK, 1997-2004. Journalism studies. 2004, vol. 5, no. 3, p. 325-338. Prieiga per internetą: $<$ http://dx.doi.org/10.1080/1461670042000246089>.

${ }^{25}$ McNair, B. An introduction to political communication. $3^{\text {rd }}$ ed. London: Routledge, 2003, p. 130-162. 
kuri ne tik tenkina politikų ir politinių institucijų, bet ir žiniasklaidos poreikius);

- ịvaizdžio vadybą (politiko ar politinès institucijos konstruojamą kalbėseną ir veiklos pristatymą, politinị stilių ir išskirtinumą; ji neatsiejama nuo sẻkmingų ryšių su žiniasklaida, kai siekiama sukuriant gerus santykius su žiniasklaidos atstovais užsitikrinti žiniasklaidos palankumą);

- politinę rinkodarą (dažniausiai siejamą su politine reklama, mažiau - su kitomis politinès rinkodaros priemonemis (ịvairia atributika, tokia kaip degtukai ar druska, kalendoriai ar saldainiai), kurių esminé užduotis - sukurti ir rinkejjams pasiūlyti atitinkamą prekès ženklą (politiką, politinę instituciją) (kas?), nurodyti, kokiai auditorijai $(k a m$ ?) ir kodèl jis yra priimtinas ir turi būti pasirinktas (kodèl?);

- vidinę komunikaciją politinèje institucijoje (komunikacija politinès institucijos viduje ar tarp politikų, politinès partijos ar pilietinio judejjimo narių, kuri skatina / didina narių ịsitraukimą ne tik i patị komunikacijos procesą, bet ir ị institucijos veiklą).

Politinių ryšių su visuomene užduotis - kurti pasakojimus apie politiką, tačiau šioje veikloje dažnai susiduriama su žiniasklaidos veiklos ypatumais, ypač tais, kurie ryškejja politinejje žurnalistikoje, t. y. nors ir juntamas didelis poreikis politiniams pasakojimams, tačiau susiduriama ir su žiniasklaidoje kuriamu „meilès - neapykantos“ supriešini$\mathrm{mu}^{26}$.

Kaip pastebi Brissendenas ir Moloney ${ }^{27}$, politiniai ryšiai su visuomene dažnai yra naudojami ir kaip gynybinè priemonė, kuria politikai ir politinès institucijos stengiasi apsisaugoti ar apsiginti nuo kritinių

${ }^{26}$ McNair, B. PR must die: spin, anti-spin and political public relations in the UK, 1997-2004. Journalism studies. 2004, vol. 5, no. 3, p. 325-338. Prieiga per internetą: $<$ http://dx.doi.org/10.1080/1461670042000246089>.

${ }^{27}$ Brissenden, J., Moloney, K. Political PR in the 2005 UK general election: winning and losing, with a little help from spin. Journal of marketing management. 2005, vol. 21, no. 9/10, p. 1005-1020. Prieiga per internetą: <http://dx.doi.org/10.1362/ $026725705775194175>$. 
žiniasklaidos pranešimų, patys rengia politinius pranešimus. Dèl politikų taikomų ryšių su visuomene priemonių ir siekio pateikti save, idejas, politines problemas ar jų sprendimus susiduriama su tam tikru žiniasklaidos pasipriešinimu, nes dažnai politiniai ryšiai su visuomene interpretuojami kaip „verpste““28 (angl. spin) kaltinant paslèptų veiklų ìsukimu ir daroma įtaka pažeidžiant demokratijos vertybes.

Dažnai politinių ryšių su visuomene veikla siejama su realybès (ivykių) konstravimu (Edelman tokią veiklą vadina „politinio spektaklio konstravimu“"29), kai pasitelkiant tiek komunikacijos specialistus, tiek žiniasklaidą yra kuriamas politiko, politinès institucijos matomumas, aktualinama atitinkama problema, i̇vykis, jų dalyviai ar kontekstas.

Politinius ryšius su visuomene pagal siekiamus strateginius tikslus būtų galima skirstyti ị mobilizuojančią (ịtraukiančią atitinkamas suinteresuotųjų grupes ị politinę komunikaciją ryškinant svarstomos problemos ar iškeliamos temos aktualumą atitinkamoms suinteresuotụjų grupėms) ir rinkodaros, kuria siekiama pristatyti politiką, politinę instituciją ar politines idejas, problemas ar paskatinti pritarti, paremti siūlomus jų sprendimo būdus.

Mobilizuojanti veikla daugiau skirta informacinei žmonių kontrolei ir naudojama siekiant nukreipti žmonių veiksmus norima linkme. Be šių priemonių negali išsiversti nè viena valstybė, kuri suinteresuota patraukti kuo daugiau jos politiką palaikančių subjektų.

Priešingoje pusèje yra rinkodarinès strategijos, kurios formuojamos atsižvelgiant ị politinių ryšių su visuomene užsakovą ir informacijos perdavimo priemones, kuriomis yra siekiama perduoti atitinkamą informaciją tinkamu laiku ir reikiamoje vietoje. Šios priemonės dažnai yra taikomos siekiant ịtikinti žmogų, suinteresuotųjų grupę (taip pat ir rinkejjus) ar visuomenę. Tokios strategijos pabrèžia politikos subjektų

${ }^{28}$ McNair, B. PR must die: spin, anti-spin and political public relations in the UK, 1997-2004. Journalism studies. 2004, vol. 5, no. 3, p. 325-338. Prieiga per internetą: $<$ http://dx.doi.org/10.1080/1461670042000246089>.

${ }^{29}$ Edelman, M. Politinio spektaklio konstravimas. Vilnius: Eugrimas, 2002. 139 p. 
vykdomą auditorijų informavimą apie tikslus ir uždavinius, pabrèžiant grị̌ztamąji ryši, dialogą, sąžiningumą ir abipusę pagarbą. Siekiant šių tikslų yra analizuojami informacijos poreikiai, pasitikejimas informacija ir jos šaltiniai tam, kad būtų pasirinkta siūloma politinė elgsena.

Aptartos politinių ryšių su visuomene priemonès, vykdomos veiklos rodo, kad viešojoje erdvèje dominuoja klaidingas politinių ryšių su visuomene veiklos pristatymas, dažniausiai siejamas vien tik su politiko ar politinès institucijos siekiu sukurti matomumą, išryškinti atitinkamą problemą ar pagrịsti tam tikro sprendimo būtinybę; politiniai ryšiai su visuomene yra platesnè, strateginė komunikacijos veikla, kuri, tinkamai taikoma, galètų padèti politikams ir politinèms institucijoms pasiekti gerų, tarpusavio supratimu grịstų santykių su svarbiomis suinteresuotųų grupėmis, ypač rinkejjais, politiniais partneriais ir opozicija, kuriant politines žinias, supratimą apie politinius įvykius, galiausia - politinę kultūrą.

\section{Išvados}

Politinių ryšių su visuomene sritis yra įdomi ir intriguojanti, tačiau dèl veiklos specifikos ji lieka paslaptinga, todèl politinių ryšių su visuomene specialistai susiduria su tam tikrais mitais, kuriems paneigti ir yra parengtas šis straipsnis.

1 mitas. Politinių oponentų kaltinimai dèl viešųjų ryšių taikymo siekiant pristatyti organizuojamas akcijas, ryškinant atitinkamas problemas. Jei politinius ryšius su visuomene suvokiame kaip informacijos sklaidą apie atitinkamas politines idejjas, politinius veiksmus, tada viešaisiais ryšiais reikètų vadinti abiejų pusių (tiek kaltinančiojo viešaisiais ryšiais, tiek apkaltintojo viešųjų ryšių taikymu) vykdomą komunikacinę veiklą: juk per komunikaciją yra pristatomas politikas, politinè ideja, veiksmas ar politinè institucija, atkreipiamas visuomenès, taip pat ir žiniasklaidos dèmesys ị atitinkamus ịvykius, problemas, kartais pasiūlant atitinkamus sprendimus, siekiant sulaukti palaikymo. 
2 mitas. Viešieji ryšiai politikoje dažnai yra susiejami su politiko ar politinès partijos, kitos institucijos ìvaizdžio formavimu. Tai tiesa, kaip ir buvo teigiama straipsnyje: politiniai ryšiai su visuomene suteikia politikams, politinems institucijoms priemones, kurias naudodami jie gali pateikti save (ir kaip politikus, ir kaip tam tikros srities ekspertus, ir kaip paprastus žmones), atstovaujamas politines institucijas ar ideologijas, taip kurdami, ịtvirtindami ar silpnindami savo ịvaizdi, t. y. dalyvaudami viešojoje erdvejje politikai, politinių institucijų atstovai yra matomi, todèl jų veiksmai interpretuojami - tai ir yra įvaizdžio pagrindas. Todèl nuo politikų, politinių institucijų gebejjimo tinkamai „papasakoti“ istoriją, išryškinti problemas ar temas, kurios aktualios rinkejui ar tam tikrai visuomenès grupei, sukelti, o gal ir slopinti tam tikrus jausmus, priklauso ir kuriami ivvaizdžiai. Verta pastebèti, kad politiko ar politinès institucijos ịvaizdis bus naudingas ir lems laukiamą rezultatą tik tada, kai jis bus planuojamas, tęstinis, nuoseklus, t. y. kai politiko ar politinès institucijos veiksmai neprieštaraus vieni kitiems, bus atpažistami. Žinoma, ịvaizdis gali susiformuoti ir spontaniškai, netikslingai, tačiau tada gali kilti politiko ar politinès institucijos atpažinimo ar nepakankamos sąsajos su atitinkama tema, tematika problema.

3 mitas. Viešieji ryšiai yra veikla, kuria norima atkreipti dèmesi $i$ politiką, siekiant padidinti jo populiarumą, ir dažnai tai nèra siejama su politine veikla. Yra atlikta keletas tyrimų, kuriais remdamiesi turètumème sutikti su šiuo teiginiu, nes šiuolaikinèje visuomenejje vyrauja domejjimasis reginiais, įvaizdžiais, o ne politikos esme, todèl, siekdami atkreipti rinkèjų dèmesį, išsiskirti iš kitų politikų, jų pristatomų idèjų ar temų, kurios iškeliamos pasisakymuose, politikai dažnai naudoja specialiai visuomenès dèmesiui atkreipti sukurtus reginius. Tiesa, politiniuose ryšiuose su visuomene taikomas „isukimo“, arba „verpstès“, būdas, kai siekiama nukreipti visuomenès dèmesị nuo vienų temų $\mathfrak{i}$ kitas, nuo vieno ịvykio sukuriant kitą ir pan. Tačiau tokie veiksmai, kad nesukeltų ittarimo (o tai jau lemtų abejonių politiku (ar politine institucija), jo atvirumu, sąžiningumu ir tai pakenktų jo įvaizdžiui ir 
verstų abejoti visais politiko (ar politinès institucijos) veiksmais), turi būti labai kruopščiai suplanuojami, vykdomi, todèl yra brangūs ir taikomi išskirtiniais atvejais.

4 mitas. Nesvarbu, kas ir kaip komunikuojama, - svarbu, kad politikas ar politinè institucija būtų matomi. Pastaruoju metu viešojoje erdvejje nemažai informacijos apie politikų asmenini gyvenimą, neištikimybę, apgaulę siekiant pasipelnyti, - visa ši informacija nelieka nepastebėta rinkejjo, todèl vertètų prisiminti esminius ryšių su visuomene veiklos principus: atvirumą, skaidrumą, patikimumą, aiškumą, kurie ir parodo, kad svarbu ne tik tai, kas komunikuojama, bet ir tai, kad komunikacija turi būti atvira, skaidri, atsakinga ir tai turi matytis visuose komunikaciniuose politiko (ar politinès institucijos) pranešimuose: kalbėsenoje, politinèje veikloje, atliekamuose veiksmuose, kasdieniame gyvenime.

5 mitas. Žiniasklaidos svarba politiniuose ryšiuose su visuomene: politikai ir politinès institucijos, siekdami palankaus žiniasklaidos dèmesio, yra linkę kalbèti populiariai apie politiką, politines problemas, todèl kyla politikų reitingai, jais yra labiau pasitikima, o ir per rinkimus jie gauna rinkèjų palaikymą. Iš dalies šis mitas teisingas, nes politiko ar politinès institucijos matomumas leidžia jiems iškelti visuomenei ne tik aktualias temas ir problemas, bet ir pristatyti galimus jų sprendimo būdus. Tačiau populiarumas gali lemti ir tam tikras problemas: dažnas politiko šméžavimas televizijoje, ypač pramoginèse laidose, gali lemti rinkèjų nepasitikejjimą juo. Todèl turi būti labai aiškiai paskirstomas dėmesys tarp žiniasklaidos ir esminès politinès veiklos. 


\section{Literatūra}

Brissenden, J., Moloney, K. Political PR in the 2005 UK general election: winning and losing, with a little help from spin. Journal of marketing management. 2005, vol. 21, no. 9/10, p. 1005-1020. Prieiga per internetą: < http://dx.doi.org/10.1362/026725705775194175>.

Edelman, M. Politinio spektaklio konstravimas. Vilnius: Eugrimas, 2002. 139 p.

McNair, B. An introduction to political communication. $3^{\text {rd }}$ ed. London: Routledge, 2003. 250 p.

McNair, B. PR must die: spin, anti-spin and political public relations in the UK, 1997-2004. Journalism studies. 2004, vol. 5, no. 3, p. 325-338. Prieiga per internetą: <http://dx.doi.org/10.1080/146167004 2000246089>.

Froehlich, R., Rüdiger, B. Framing political public relations: measuring success of political communication strategies in Germany. Public relations review. 2006, vol. 32, p. 18(18-25). Prieiga per internetą: <sciencedirect.com>

Street, J. Mass media, politics and democracy. Palgrave, 2001. 297 p.

Тургаев, А.С., Хренов, А.Е. Политология в схемах и комментариях. 2005. 


\section{POLITICAL PUBLIC RELATIONS: PUBLIC PRESENTATION OF REAL WORKS OR TOOL TO BLAME OPPONENTS FOR INADEQUATE ACTIVITIES?}

\section{RENATA MATKEVIČIENE்}

Keywords: political public relations; (mass) media; politicians; political institutions; political parties; public relations; media relations; image.

\section{Summary}

In the public sphere, especially before elections, discussions about the possibilities of political communication or techniques of public relations could show that politicians are familiar with the means of political public relations and they tend to see those means applied by their political opponents via presentation of problems and their solutions, suggested procedures to consolidate political partners and electorate for some decisions, etc.

Politics is a field in which modern communications and public relations were invented, and in this field public relations could help present ideas, organize discussions on topics that are important for groups of society. In politics, public relations is essential not only during political election campaigns when voters are introduced to policies or political parties, politicians, but also on a daily basis, because only because of communicating with each other and with the public and relevant stakeholders groups politicians and political institutions can ensure the enforcement of the policy: formation of governments, coalitions, to address public interest issues and trade-offs in negotiating party or parties with different representatives, businessmen and politicians of other countries . Political public relations covers a wide range of communication means, so it sometimes becomes annoying when politicians in the public space treat public relations only as a political desire to be visible and popular.

The aim of this article is to present definition and discussion about political public relations, their characteristics, principles, in order to refute the prevailing media myths about public relations activities.

This article analyzes political public relations activities, processes and means that are used for political public relations. In the article the main fields of activities of public relations such as media relations, image management, and internal political communication are presented. In the conclusions the myths related with political public relations are discussed: usage of term public relations to strengthen populist aspects of political opponents' activities, importance of media relations and image formation, visibility creation and political spectacle as the main activities of political public relations.

Iteikta 2014 m. spalio 9 d. 